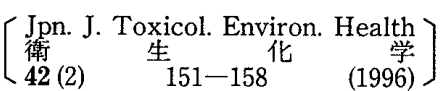

閉鎖系室内におけるオソンン生成・分解装置の性能評価に関する研究

一三機種の試験 —

渡辺文夫, ${ }^{a}$ 福岡勝義, ${ }^{b}$ 大谷敏之 $^{b}$

東京都立国際高等学校, ${ }^{a}$ 秼田村金属製作所 ${ }^{b}$

\title{
Studies on the Efficiency Assessment of Equipments for the Formation and Decomposition of Ozone in the Closed Room-Tests Using Three Types of Equipments-
}

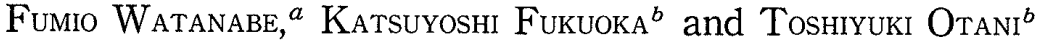 \\ Tokyo Metropolitan Kokusai Senior High School, ${ }^{a}$ 2-19-59, Komaba, Meguro-ku, \\ Tokyo 153, Japan and Tamura Metal Manufacturing Co., Ltd., ${ }^{b}$ 424-1, \\ Kamimabushe, Kadoma-shi, Osaka 571, Japan
}

(Received July 24, 1995)

The efficiency of commercially available equipments for ozonization by ultraviolet rays in the rooms was measured and assessed.

The volume of the room was enlarged to $4.5 \mathrm{~m}^{3}$ and to $54 \mathrm{~m}^{3}$, and then, the tests were held using three types of ozonization equipments.

By considering the data including the results of the tests in the small room, the formulas and the line graphs on the relationships between the room volume and the ozone concentration of the steady state, and those between the ozone concentration of the steady state and the input current of a lamp were obtained.

As the result of this experiment, a new phenomenon was found out, that is, the apparent velocity of ozone photo-decomposition by an ultraviolet ray lamp having a constant initial current was slower than that of the spontaneous decompositions, when the room volume was enlarged beyond a certain degree.

This phenomenon was named an inversion volume.

The overall assessments of these three kinds of equipments were as follows:

1) In the case of the ozone formation those equipments are useful, because they are efficient enough to obtain the ozone concentration of the steady state within an hour, though the time consumed to achieve it varies according to its room volume.

2) In the case of the ozone decomposition in the ordinary laboratory, as far as the decomposition velocity is concerned, setting up one ultraviolet ray lamp and one ozone lamp can be less effective than those of the spontaneous decomposition.

Therefore, to increase the decomposition velocity, it is necessary to increase the input current of one ultraviolet ray lamp, or to set up the lamps in parallel.

3) In the extremely clean room, such as a bioclean room, the ozone decomposition by ultraviolet ray (using $140 \mathrm{~W}$ big type of double wall) is thought to be useful.

Lastly, the efficiency assessments and the comparisons of all the equipments (including the following system) measured in the past was conducted, and therefore, the one in which the greatest improvement could be made was found.

Key words — ozone; ultraviolet ray ; room volume ; efficiency assessment ; ozonization equipment 


\section{緒}

著者らは今までに，無オゾン及び既に若干のオゾ ンを含む空気または酸素に紫外線（主力輝線波長 $184.9 \mathrm{~nm})$ を照射してのオゾンの生成, さらに紫外 線（主力輝線波長 $253.7 \mathrm{~nm}$ ）を照射してのオゾンの 分解に関して，オゾン濃度のコントロールをいかに 効率良く行うかについて研究してきた。

初期の研究では，ガラス製環状二重管構造の流動 通過系 (以下流通系) 装置による種々の測定を行い, 基本的現象や装置性能を把握し報告した. ${ }^{1-9)}$

さらに，閉鎖系室内におけるオゾンの生成・分解 に関し市販のオゾン化装置を用いて諸現象を測定 し，装置性能について評侕を行った。

すでに本誌前報においては，比較的容積が小さい 試験室で同一機種によるオゾン化実験を行い，オゾ ンランプ数, UV ランプ数, 初期オゾン濃度, 残留オ ゾン濃度，到達定常濃度，反応開始時間，反応完了 時間などの各種要因相互の関係式や線困を得ること で，閉鎖系室内でのオゾン濃度のコントロールを行 うための幾つかの手掛かりを把握し報告した。 ${ }^{10)}$

本報ではさらに, 小部屋及び大部屋において, 出 力の異なるオゾン化装置を数種類使用した場合の 各々の性能を評価して，オゾン濃度のコントロール に，より一層具体的な手掛かりを与えようとするも のである。

前報では, 閉鎖系における詳細な基礎研究を行い, 考察に当たっては従来の文献に報告されている光化 学の分子，原子レベルのデータや，物理化学の反応 速度論的な面からの考察と現箺のオゾン化装置から 得られる結果とを比較検討してきた。

本報では，前報での基礎的研究による知見を深め た上で，閉鎖系でのスケールアップ実験を行った。

試験室容積を $4.5 \mathrm{~m}^{3}$ 及び $54 \mathrm{~m}^{3}$ とし, 使用装置は TM-38 W に加えてTM-60,TM-140の 3 機種と, ラ ンプ入力で約 3.7 倍まで増加させた.

この規模は現実に操業を行っている室の大きさ， 装置の容量であり，そこから得られるデー夕は新た に装置を設置する際に十分な手掛りとなり得るもの と考之る。

今回の実験では，前報のように詳細なデー夕解析 に専念せず,むしろ大局的な観点でデー夕を解析し， 現実に使用者が要望する数值及び設計担当者が必要 とする数值を把握することを大きな目的とした。

\section{実 験 の 部}

1. 使用機材 1）密閉試験窒— [小部 屋]：容積：約 $4.5 \mathrm{~m}^{3}$. 室内表面：水性ペンキ塗装 木製ドア $1.5 \mathrm{~m}^{2}$ ，コンクリート床 $2.0 \mathrm{~m}^{2}$ ，モルタル 塗り白壁 $11.7 \mathrm{~m}^{2}$.

[大部屋] : 容積：約 $54.2 \mathrm{~m}^{3}$. 室内表面：水性ぺ ンキ塗装木製ドア $3.1 \mathrm{~m}^{2}$, コンクリート床 $24.7 \mathrm{~m}^{2}$, モルタル塗り白壁 $61.2 \mathrm{~m}^{2}$, ガラス (空) 面 $0.9 \mathrm{~m}^{2}$, 鉄材表面 $0.1 \mathrm{~m}^{2}$.

2）オゾン濃度测定器——本誌前報 ${ }^{10)}$ と同じ.

3）紫外線オゾン化装置——田村金属製作所製 スペースくりん TM-38 W, TM-60, TM-140, 各 1 台.

3 機種の寸法図は前報 ${ }^{10)}$ Fig. 1 に示したTM-38 $\mathrm{W}$ と同様であるが，異なる寸法 $(\mathrm{mm})$ は本体長さ $\times$ 高さ ×幅で，TM-60は $1000 \times 97 \times 130 ， T M-140$ は $1400 \times 160 \times 200$ である.ランプの寸法は全長：フィ ラメント間距離：管径で, TM-60 は 860：770：15, TM-140 は 1191：980：38である.

また，ランプのスペクトルは 3 種共に主力輝線波 長 $254 \mathrm{~nm}$ であり，オゾンランプはその他に $185 \mathrm{~nm}$ にも小さいピーク $(4-5 \%)$ が認められた。

また，各ランプの $254 \mathrm{~nm}$ の放射照度と距離の関 係の測定值を Fig. 1 に示した。測定器は東京光学社 製のトプコン 254-UVRを用いた。

2. 試験方法密閉試験室内にスペースくりん を 1 台ずつ設置してオゾン化反応を行い，室中央部 のオゾン濃度を以下に示す 3 種類の項目について追 跡した。

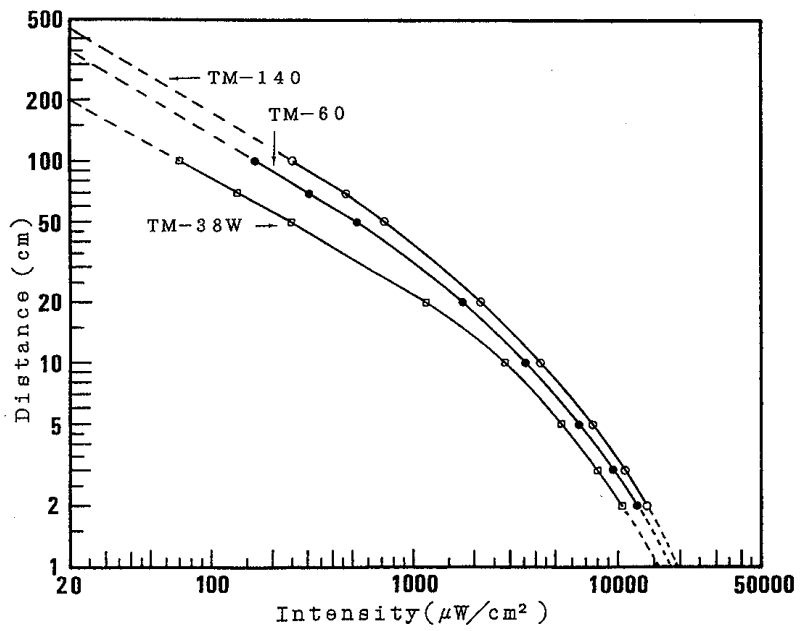

Fig. 1. Relation between Intensity of Illumination (254 nm) and Distance 
1）オゾンランプ点灯によるオゾン生成能力を測 定・評価した。

2）オゾンを定常值の濃度に到達させた後，オゾ ンランプを消灯してオゾンの自然分解速度を測定し た.

3）オゾンが定常值の飽和濃度に達している状態 でUVランプを照射してオゾンのUV 分解能力を 測定・評価した。

\section{結 果 及び考察}

Fig. 2 は，オゾンの生成についての 3 機種のデー 夕を一括したものである。（a）は小部屋，(b) は大
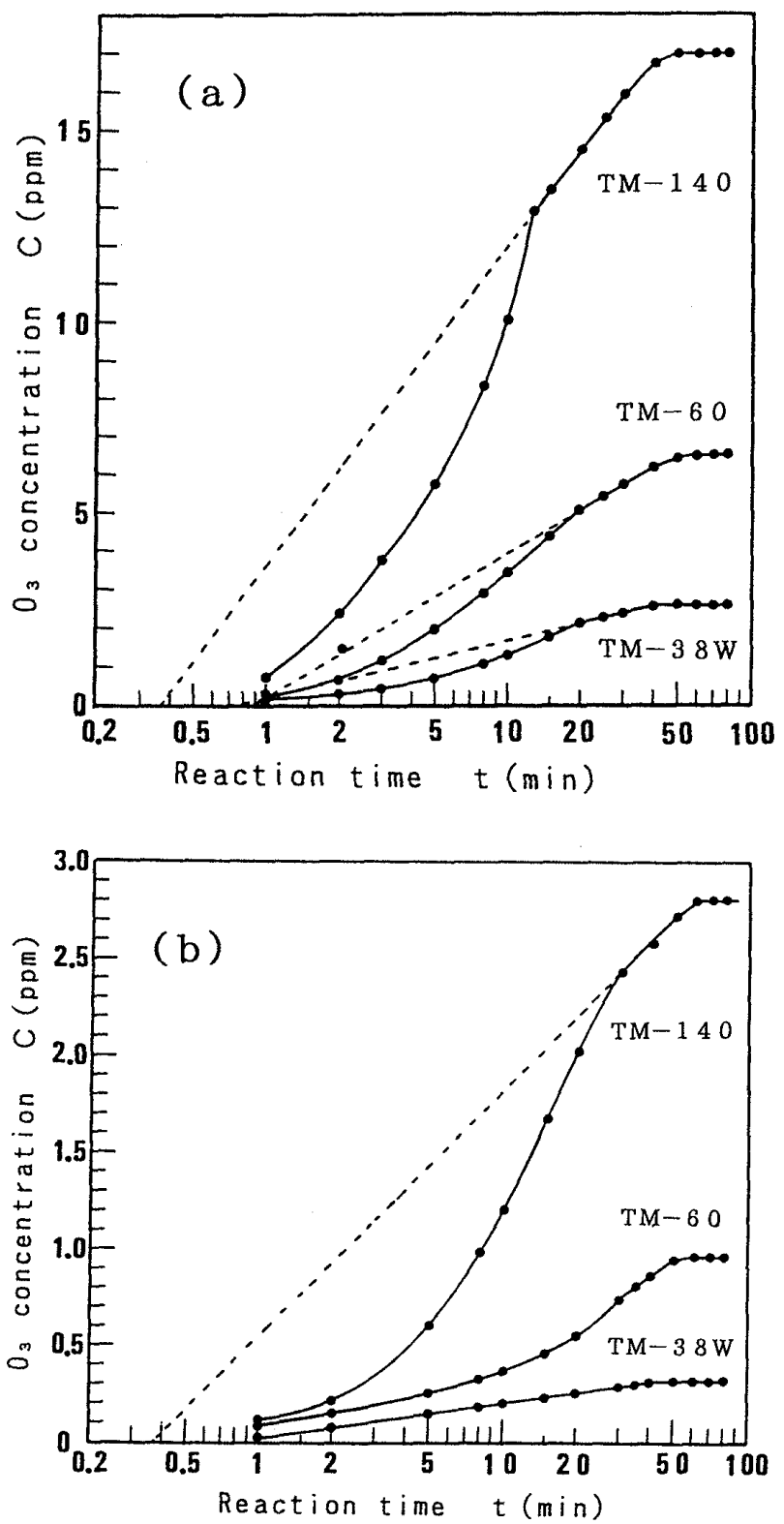

Fig. 2. Ozone Formation

(a) In the small room. (b) In the big room.
部屋についてのデータである.

(a)，（b）いずれの場合も，生成初期はオゾンが消 費されるが, 経時的に急激な濃度上昇を示し, 次い でグラフ上で直線関係を示した後に定常状態の濃度 $C_{\mathrm{S}}$ に達した。

（a，（b）を比較して，室容積又は壁面積の変化に 対して $C_{\mathrm{S}}$ の值が対応するか否かを検討してみた.

TM-140, TM-60, TM-38 W の $C_{\mathrm{S}}$ について小部 屋の值対大部屋の值は各々 $17 / 2.7=6.3,6.5 / 0.3=$ $6.5,2.5 / 0.3=8.3$ である.

つぎに, 大部屋対小部屋の容積比は $54.2 / 4.5=$ 12.0 , 面積比は $90.0 / 15.2=5.9$ であることから, $C_{\mathrm{S}}$ は室容積よりも壁面積の変化に関連性を有するよう に考えられる。しかし，このデータでは室壁面の性 状が異なるので，現時点では断言できない.

Fig. 3 は，オゾンの自然分解とUV 分解について のデータを一括したものである。（a）は小部屋，(b) は大部屋についてのデータである。

（a）では，三者共にUV 分解の方が自然分解より も見かけの分解開始時間 $t_{\mathrm{d}}$ と分解完了時間 $t_{\mathrm{f}}$ が速 いことが確認される。

また， $C_{0}$ が高濃度のときの方が $t_{\mathrm{f}}$ が短いことも 認められる。

なお，各プロットの右端で $\mathrm{O}_{3}$ が低濃度になると 直線よりもやや右側にずれる傾向がある。これは， 室内のオゾンの拡散速度と測定器の感度が原因と考 えられる。

（b）の全体的な特徵は小部屋でのデータと同様で あるが，注目すべきはTM-38 W については自然分 解の方がUV 分解よりも分解完了時間 $t_{\mathrm{f}}$ が小さい という点である。

このことは従来の現象からは背反する結果であ る.オゾンを分解する $254 \mathrm{~nm}$ を照射した場合に, 自 然分解の場合よりも分解開始及び完了が遅くなるこ とは，従来とは別の意味での「逆転現象」である。

従来の「逆転現象」とは，著者が以前に報告した 「逆転域」のことであり,1-9) 単一ランプを用いた装 置の流路中でUV $185 \mathrm{~nm}$ と $254 \mathrm{~nm}$ との放射照度 差とUV 照射時間の長短が主要因となって, 生成才 ゾン濃度が増加から減少へと急激に移行する現象の ことである。

しかし，今回の「逆転現象」は閉鎖系においての現 象で，オゾン生成ランプ 1 灯の現象ではなくオゾン 分解用ランプによる分解速度と壁面を中心とする自 然分解の反応速度の差に起因するものと考えられ る。過去の文献における閉鎖系に関する報告11-13)で 
Vol. 42 (1996)
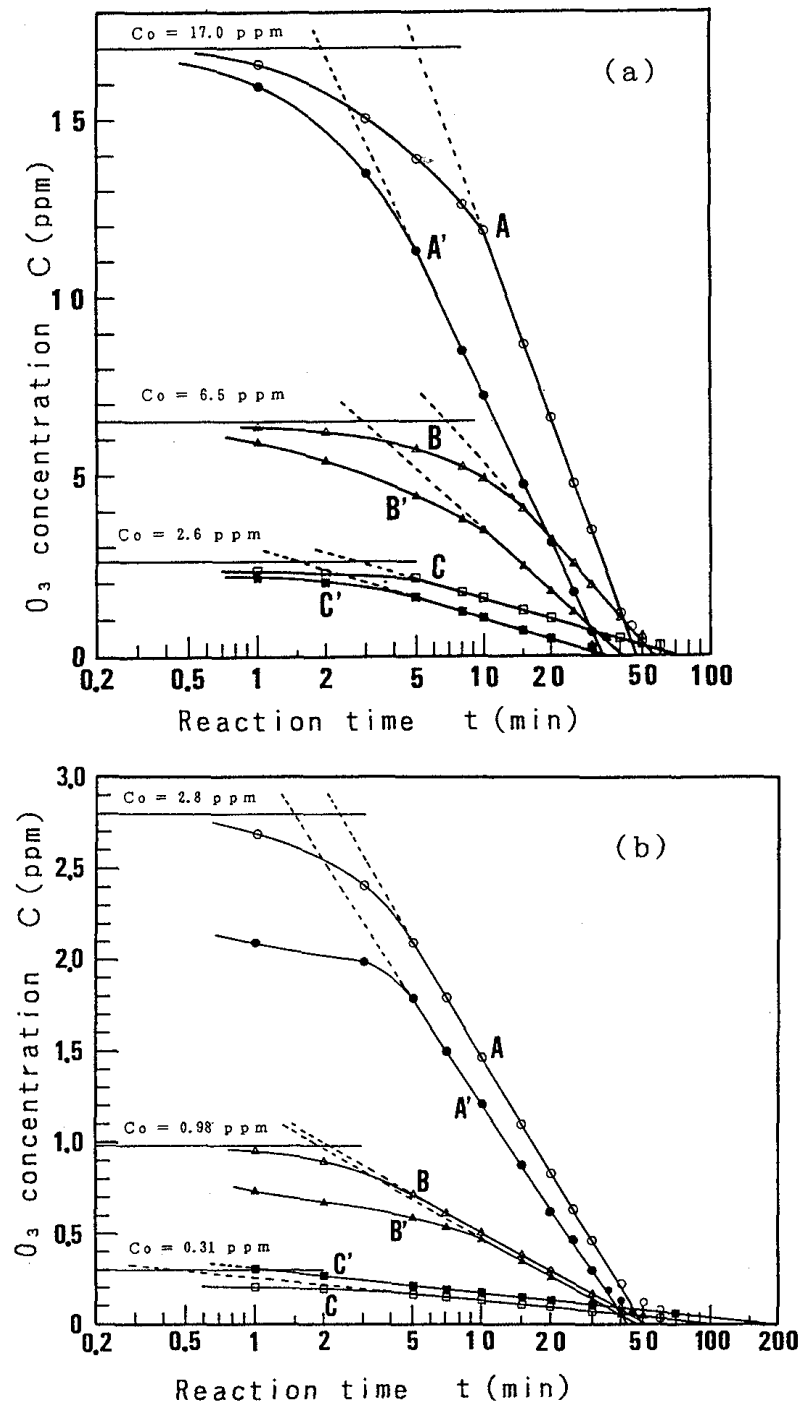

Fig. 3. Ozone Decomposition

(a) In the small room. (b) In the big room.

A, spontaneous decomp.; A', UV decomp. by TM140 ; B, spontaneous decomp. ; B', UV decomp. by TM60 ; C, spontaneous decomp. ; $\mathrm{C}^{\prime}$, UV decomp. by TM$38 \mathrm{~W}$.

も，ガラス壁面に関する自然分解を若干は考察して いるものの，逆転現象について言及しているものは なく,今回の実験で新たに見い出されたものである.

既にガス流量域の変化から「逆転域」という用語 が照明学会を始めとする各学会で認められている現 在，著者は新たに「逆転容積」及び「逆転入力」と いう仮称を用い，以下のように定義した。

1）初期オゾン濃度一定の閉鎖室内において入力 一定のUVランプによる光分解を行うとき, 室容積 （又は壁面積）を大きくしていくと，ある容積（又は 面積）の值を境にして見かけの光分解速度が見かけ の自然分解速度より遅くなる。この逆転現象が起こ
る室容積 (又は面積)を「逆転容積 (又は逆転面積)」 と呼ぶ。

2）初期オゾン濃度一定で容積一定の閉鎖系室内 においてUVランプによる光分解を行うとき, ラン プ入力を小さいものにしていくと，ある入力の值を 境にして見かけの光分解速度が見かけの自然分解速 度より遅くなる。この逆転現象が起こるランプ入力 を「逆転入力」と呼ぶ。

今回，「逆転容積 (又は逆転面積)」と「逆転入力」 とを併せた意味での，見かけの「逆転現象」につい ての理論的な解析を行うに十分なデータが現在は不 足であるが，強いてその原因を考察すると，自然分 解の見かけの分解開始時間 $t_{\mathrm{d}}$ の遅れを考察した前 報の反応機構に立ち返って解析するしか方法は無 い.

$$
\begin{aligned}
& \mathrm{O}_{3}+\mathrm{M} \rightarrow\left[\mathrm{O}_{3}-\mathrm{M}\right] \rightarrow \mathrm{O}_{2}+\mathrm{O}+\mathrm{M} \\
& \mathrm{O}_{3}+\mathrm{O} \rightarrow 2 \mathrm{O}_{2} \\
& \therefore \quad 2 \mathrm{O}_{3}+\mathrm{M} \rightarrow 3 \mathrm{O}_{2}+\mathrm{M}
\end{aligned}
$$

（M は第 3 者の固体表面）

壁面での接触分解又は空中での自然分解での素反 応の1つに（1）式が，また，UV 分解での素反応の 1つに（4）式がある.

$$
\mathrm{O}_{3}+\boldsymbol{h}_{\boldsymbol{\nu}} \rightarrow \mathrm{O}\left({ }^{1} \mathrm{D}\right)+\mathrm{O}_{2}\left({ }^{1} \Delta\right)
$$

(1)，(4)式によって生成される原子状酸素が，(2) 式で示したように共にオゾンを分解する。

供給される $(\mathrm{O})$ の量は自然分解からのものと UV 分解からのものが加わり，常に増加する。 したがっ て一般的にはオゾンの総分解量はUV 分解の方が 常に自然分解のみのときよりも多くなるはずであ る.

ところが，（O）の量がある程度多くなると，一部 で次の反応の速度が増加していくことが考えられ る.

$$
\begin{aligned}
& 2 \mathrm{O}+\boldsymbol{h} \boldsymbol{\nu} \rightarrow \mathrm{O}_{2}{ }^{*} \text { (励起) } \\
& \mathrm{O}_{2}{ }^{*}+\boldsymbol{h} \boldsymbol{\nu} \rightarrow \mathrm{O}_{2} \\
& \text { このように }(\mathrm{O}) \text { または }\left(\mathrm{O}_{2}{ }^{*}\right) \text { の減少は, } \\
& \mathrm{O}_{3}+\mathrm{O} \rightarrow 2 \mathrm{O}_{2} \\
& 2 \mathrm{O}_{3}+\mathrm{O}_{2}{ }^{*} \rightarrow 4 \mathrm{O}_{2}
\end{aligned}
$$

（7），(8) 式などの分解反応が阻害される可能性が考 えられる。

すなわち，(O) の生成量はある一定量を超えると 減少の方向に傾き，結果的に見かけの $\mathrm{O}_{3}$ の分解速 度は小さくなっていくことが考えられる。

したがって，壁面が極めて清浄で $\mathrm{O}_{3}$ の分解作用 をほとんど示さないようなバイオクリーンルームな どでは，UVによる分解は極めて有効であると言之 
る.

現時点のデータで見る限り，同一ランプによる UV 分解の場合には室容積がある一定値を超えると 自然分解量が多くなってきて, そこで逆転現象が起 こる. また，一定容積の実験室でランプ入力を增加 していくと，ある一定入力から見かけ上の逆転現象 に入ることから, 合理性が認められる。このことは, 流通系反応装置での「逆転域」がガス流量を減少さ せて行くと現れることとは異なる現象である.

これらの逆転現象は本報の実験で見出されたこと であり，その発生原因を究明する意図の下での実験 ではないことから, 解析に必要なデー夕の種類と量 が少なすぎる.

また，本研究で室容積を重要な要因と考えている 以上，室内壁表面積及び性状に関しても，生成又は 残留オゾン濃度に影響を及ぼすかどうかを調べる必 要がある.

したがって，この現象の詳細な究明については今 後の課題としたい.

Fig. 4 は, 小部屋及び大部屋でのオゾンの生成に ついての, ランプ電流の総量 $(\mathrm{A})$ に対しての定常状 態のオゾン濃度 $C_{\mathrm{S}}$ の関係をプロットしたものであ る.

ランプ電流は, TM- $38 \mathrm{~W}$ は $0.24 \mathrm{~A}, \mathrm{TM}-60, \mathrm{TM}-$ 140 は各々 $0.53 \mathrm{~A}, 1.40 \mathrm{~A}$ である.

Fig. 4 の小部屋での TM-38 W 並列とは, 前報の 実験のオゾンランプを 1 灯ずつ増加させていったと きの生成オゾン濃度の $C_{\mathrm{S}}$ である。

ランプ 1 灯点灯の場合は, 小部屋・大部屋共に $I$ (A) と $C_{\mathrm{S}}(\mathrm{ppm})$ は比例関係を示し, 次の関係式が 得られた。

小部屋： $C_{\mathrm{S}}=12.07 I-0.10$

大部屋 : $C_{\mathrm{S}}=2.00 I$

また，小部屋での TM-38 W の並列では直線関係 を示さなかったものの, ランプ数の増加に応じて $C_{\mathrm{S}}$ の増加も納得のいく值を示している.なお， $I=0.24$ $\mathrm{A}$ すなわち TM-38 W 1 台使用では, 小部屋と小部 屋並列との $C_{\mathrm{s}}$ の值は本来同一となるはずである. これが異なっているのは, 小部屋のときは装置 1 台 のみの設置であるのに対して, 小部屋並列のときは 装置 5 台を密集設置したことの違いが原因と考えら れる。

全体的に見ると, 三者共に $I=0.24 \mathrm{~A}$ では同一種 類の直線又は曲線群よりも小さい $C_{\mathrm{S}}$ を示してい る.これは, $I$ が小さいときは室内の自然分解の作用 が大きく, $C_{\mathrm{s}}$ を減少させているものと考えられる.

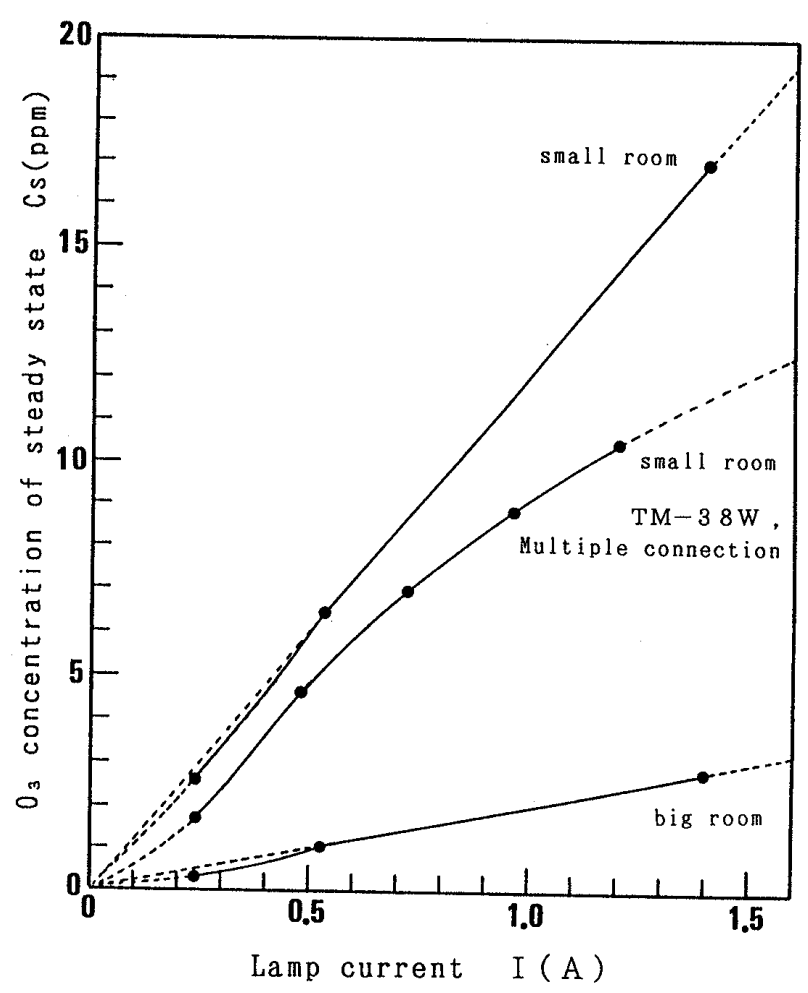

Fig. 4. Plots of Lamp Current vs. Ozone Concentration of Steady State

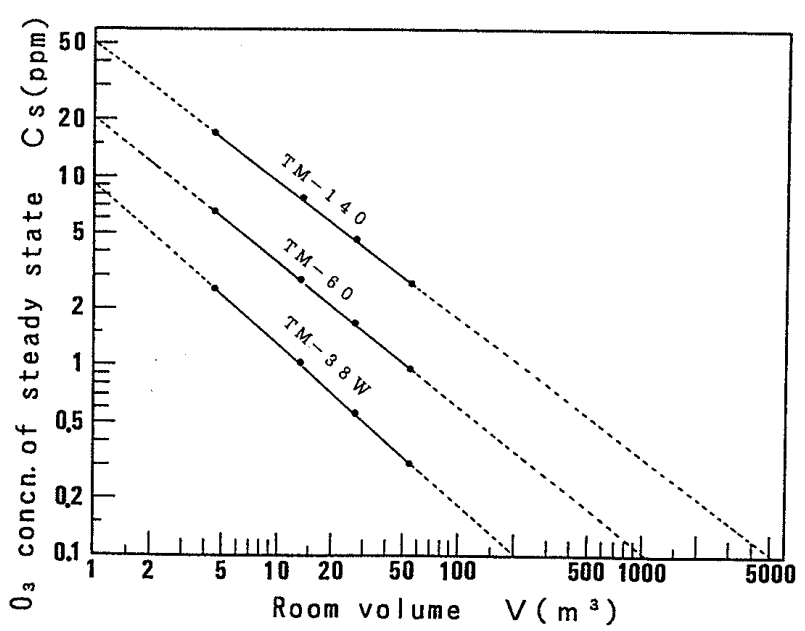

Fig. 5. Relation between Room Volume and Ozone Concentration of Steady State

Fig. 5 は，3種のスペースくりんについて実験室 の容積 $V\left(\mathrm{~m}^{3}\right)$ に対する定常オゾン濃度 $C_{\mathrm{s}}(\mathrm{ppm})$ をプロットしたものである.

ここで，大部屋をビニールシートを用いて $1 / 2 ，$ $1 / 4$ に仕切って, 異なる室容積の下での測定も追加 した.

3 種のランプの各大部屋での $C_{\mathrm{s}}$ の值は, ほぼバ ランス良く分布している.

3 種共にグラフの点線を延長した直線の関係式は 
次の通りである。

TM-140: $\log C_{\mathrm{s}}=-0.72 \log V+1.70$

TM-60 : $\log C_{\mathrm{S}}=-0.76 \log V+1.31$

TM-38 $: \log C_{\mathrm{s}}=-0.85 \log V+0.97$

Fig. 5 から, 3 機種についての室容積 $(V)$ に対す る到達可能な定常オゾン濃度 $\left(C_{\mathrm{s}}\right)$ の概略值を即座 に読み取ることができる。

\section{種々のオゾン生成装置の性能の比較}

オゾン生成装置としての性能評価を異なる機種と の間において比較吟味する必要がある。この場合, 使用しているランプの入力, ランプ寸法, 空気流路 の形状，空気流量などがそれぞれ異なる。したがっ てオゾン生成能力は，一般に $\left[\mathrm{kg} \mathrm{O}_{3} / \mathrm{h}\right]$ や $\left[\mathrm{kg} \mathrm{O}_{3} /\right.$ W] などの単位で絶対量を比較することが多い.し かし本報では，以前の測定で扱った装置 ${ }^{1-9)}$ に対し て，製品としての紫外線オゾン化装置スペースくり んはどの程度のレべルに相当するのかを何らかの尺 度で比較しなければならない。

そこで, 生成オゾン量は UV 照射時間と放射照度 の積に比例すると見なし，装置を次の 3 つのグルー プに分けて比較した。
1）基礎的研究1)に用いた種々の直管形ランプ (中・大型)

2）環状路幅と生成オゾン濃度の関係を測定した とき2)のランプ (小型)

3）スペースくりんの 3 種類のランプ (大型)

まず，スペースくりん 3 機種が一般に運転される ときのガス流量 $G(1 / \mathrm{min})$ に対する生成オゾン濃度 $C$ (ppm) を基準に考之た. TM-38 W，TM-60，TM140 は各々 $G=0.33,0.55,1.80 \mathrm{~m}^{3} / \mathrm{min}$ で $C=6.9$, 8.8, $9.8 \mathrm{ppm}$ である. 次に小型がラス製二重管群で $C=3-13 \mathrm{ppm}$ を示す $G$ は $5.01 / \mathrm{min} て ゙ あ り$, 中. 大型二重管群では $G=10.0 \mathrm{l} / \mathrm{min}$ で $C=3-18$ ppm を示すので, この条件で比較した.

Table Iには種々のオゾン生成装置の能力比較の ための諸データを示した。ガス流路の平均半径は長 径 $r_{2}$ 対短径 $r_{1}$ が 2 倍以上のものは対数平均とし た. スペースくりんの流路断面は四角形なので，相 当直径 ${ }^{14)}$ から相当半径を求めた. ランプ中心から $r$ $(\mathrm{cm})$ での UV 放射照度 $I\left(\mu \mathrm{W} / \mathrm{cm}^{2} \cdot \mathrm{s}\right)$ を以前の報 告 ${ }^{2)}$ 及び Fig. 1 から求めた. それらの数值から, 生成 オゾン濃度に対応するUV 照射量 $Q\left(\mu \mathrm{W} / \mathrm{cm}^{2}\right)$ を

TABLE I. Values about Various Kinds of Ozone Formation Equipments for the Comparison of Those Efficiencies

\begin{tabular}{|c|c|c|c|c|c|c|c|c|c|c|c|}
\hline Equipment & Lamp & $\begin{array}{l}\text { Effective } \\
\text { length } \\
l \text { (cm) } \\
\text { (between } \\
\text { filaments) }\end{array}$ & $\begin{array}{c}\text { Diameter } d_{1} \\
\text { diameter } d_{2} \\
\text { length } l_{1} \\
\text { width } l_{2} \\
(\mathrm{~cm}) \\
\end{array}$ & $\begin{array}{l}\mathrm{Sec}- \\
\text { tional } \\
\text { area } \\
S\left(\mathrm{~cm}^{2}\right)\end{array}$ & $\begin{array}{l}\text { Volume } \\
V\left(\mathrm{~cm}^{3}\right) \\
(1 \times S) \\
\end{array}$ & $\begin{array}{l}\text { Mean or } \\
\text { equiva- } \\
\text { lent } \\
\text { radious } \\
r(\mathrm{~cm})\end{array}$ & $\begin{array}{l}\text { Air } \\
\text { flow } \\
\text { ratio } \\
G \\
\left(\mathrm{~cm}^{3} / \mathrm{s}\right) \\
\end{array}$ & $\begin{array}{l}\text { Resi- } \\
\text { dence } \\
\text { time } \\
t(\mathrm{~s}) \\
(V / G) \\
\end{array}$ & $\begin{array}{l}\text { UV radia- } \\
\text { tion } \\
\text { intinsity } \\
I \\
\left(\mu \mathrm{W} / \mathrm{cm}^{2} \cdot \mathrm{s}\right)\end{array}$ & $\begin{array}{l}\text { UV radia- } \\
\text { tion } \\
\text { quantity } \\
(t \times I) \\
\left(\mu \mathrm{W} / \mathrm{cm}^{2}\right)\end{array}$ & $\begin{array}{l}\text { Ozone } \\
\text { concn. } \\
C \text { (ppm) }\end{array}$ \\
\hline \multirow{4}{*}{$\begin{array}{l}\text { Small type } \\
\text { of double } \\
\text { glass pipe }\end{array}$} & $8 \mathrm{~W}$ & 7.3 & $\begin{array}{l}d_{1}=1.3 \\
d_{2}=1.8\end{array}$ & 1.21 & 8.83 & 0.755 & 83.3 & 0.106 & 14500 & 1540 & 2.8 \\
\hline & $8 \mathrm{~W}$ & 7.3 & $\begin{array}{l}d_{1}=1.3 \\
d_{2}=2.7\end{array}$ & 4.39 & 32.0 & 0.966 & 83.3 & 0.384 & 12500 & 4800 & 6.0 \\
\hline & $8 \mathrm{~W}$ & 7.3 & $\begin{array}{l}d_{1}=1.3 \\
d_{2}=3.1\end{array}$ & 6.21 & 45.3 & 1,035 & 83.3 & 0.544 & 11000 & 5980 & 11.0 \\
\hline & $8 \mathrm{~W}$ & 7.3 & $\begin{array}{l}d_{1}=1.3 \\
d_{2}=3.4\end{array}$ & 7.74 & 56.5 & 1.095 & 83.3 & 0.672 & 10500 & 7060 & 13.0 \\
\hline \multirow{4}{*}{$\begin{array}{l}\text { Middle or } \\
\text { big type of } \\
\text { double glass } \\
\text { pipe }\end{array}$} & A, $8 \mathrm{~W}$ & 11.0 & $\begin{array}{l}d_{1}=1.3 \\
d_{2}=2.8\end{array}$ & 4.82 & 53.1 & 0.975 & 166.7 & 0.318 & 11100 & 3530 & 2.8 \\
\hline & $\mathrm{B}, 10 \mathrm{~W}$ & 30.5 & $\begin{array}{l}d_{1}=2.4 \\
d_{2}=3.1\end{array}$ & 3.02 & 92.2 & 1.375 & 166.7 & 0.552 & 9600 & 5300 & 4.1 \\
\hline & $\mathrm{C}, 15 \mathrm{~W}$ & 41.5 & $\begin{array}{l}d_{1}=2.4 \\
d_{2}=3.1\end{array}$ & 3.02 & 125.3 & 1.375 & 166.7 & 0.750 & 11000 & 8250 & 7.2 \\
\hline & $\mathrm{D}, 40 \mathrm{~W}$ & 48.5 & $\begin{array}{l}d_{1}=2.4 \\
d_{2}=3.1\end{array}$ & 3.02 & 146.5 & 1.375 & 166.7 & 0.877 & 14000 & 12300 & 18.0 \\
\hline \multirow[t]{3}{*}{$\begin{array}{l}\text { "Space } \\
\text { clean" } \\
\text { (big type of } \\
\text { double wall) }\end{array}$} & $\begin{array}{c}\text { TM- }-38 \mathrm{~W} \\
38 \mathrm{~W}\end{array}$ & 30.6 & $\begin{array}{l}d_{1}=1.5 \\
l_{1}=7.2 \\
b_{2}=16.3\end{array}$ & 113.8 & 3480 & 4.10 & 5500 & 0.661 & 6400 & 4230 & 6.9 \\
\hline & $\begin{array}{l}\text { TM-60 } \\
60 \mathrm{~W}\end{array}$ & 76.8 & $\begin{array}{l}d_{1}=1.5 \\
l_{1}=9.8 \\
l_{2}=13.2\end{array}$ & 125.8 & 9660 & 4.61 & 9170 & 1.053 & 7000 & 7370 & 8.8 \\
\hline & $\begin{array}{l}\text { TM-140 } \\
140 \mathrm{~W}\end{array}$ & 98.0 & $\begin{array}{l}d_{1}=3.8 \\
l_{1}=16.2 \\
l_{2}=20.2\end{array}$ & 304.6 & 29800 & 6.53 & 30000 & 0.993 & 6000 & 5960 & 9.8 \\
\hline
\end{tabular}




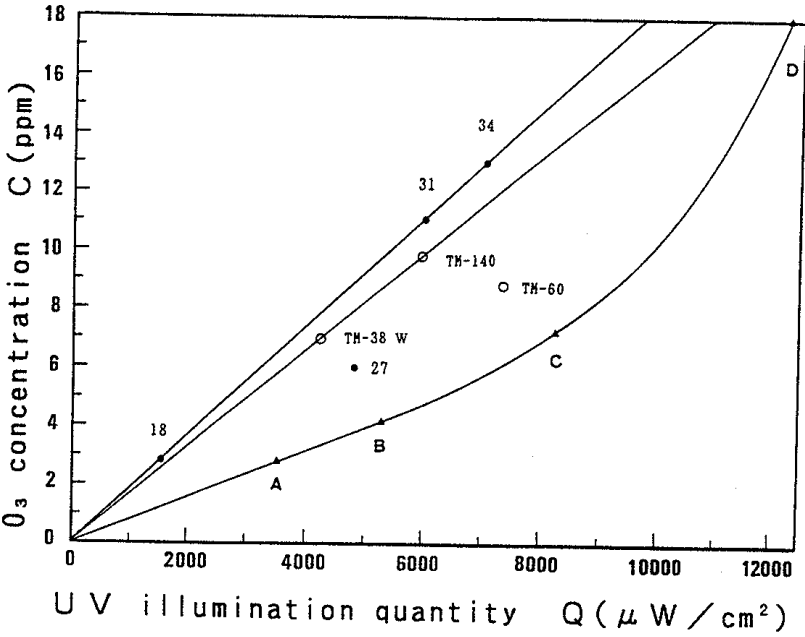

Fig. 6. Plots of UV Illumination Quantity vs. Produced Ozone Concentration about the Comparison with the Capacity of Various Ozone Formation Apparatus

, small type of double glass pipe; $\bigcirc$, "space clean" (big type of double wall); $\boldsymbol{\Delta}$, middle or big type of double glass pipe.

\section{算出した.}

Fig. 6 は種々のオゾン生成装置の能力を比較する ための生成オゾン濃度 $C$ 対 UV 照射量 $Q$ のプロッ トである.Fig. 6 において，3つのグループが明確に 識別できる. 黒丸印は小型二重管装置群で，18，27， 31,34 の数字は環状路外径 $(\mathrm{mm})$ である. $r_{2}=27 \mathrm{~mm}$ 以外は直線上にプロットされ, 関係式は次の通りで ある。

$$
C=1.84 \times 10^{-3} Q\left(\mu \mathrm{W} / \mathrm{cm}^{2}\right)
$$

$r_{2}=27$ は同じグループ内では低性能である。この ことは，以前の報告2)での各環状路外径における酸 素を原料としたときの生成オゾン量 $(A)$ と空気を原 料としたときの生成オゾン量 $(B)$ との比でも特異性 を示している。

白丸印はスペースくクんの群で, TM-60の他は以 下の直線関係を示している.

$$
C=1.65 \times 10^{-3} Q\left(\mu \mathrm{W} / \mathrm{cm}^{2}\right)
$$

TM-60 が同群の中で低性能である主因はランプ 外径が流路径に比して小さ過ぎることと容易に言え る、また，黒三角印は中・大型二重管装置群であり， ランプ A と B は以下の直線関係を示している.

$$
C=7.93 \times 10^{-4} Q\left(\mu \mathrm{W} / \mathrm{cm}^{2}\right)
$$

ランプ $\mathrm{C}, \mathrm{D}$ は顕著に高性能になっている.

Fig. 6 の直線部分の勾配がオゾン生成能力を示す ものとして黒丸印群の勾配を 1 とすると, 白丸印群 と黒三角印群はそれぞれ 0.897 及び 0.431 となる.
以上のことから，スペースくりんのオゾン生成能力 は小型ガラス製二重管装置群の約 $90 \%$ であると言 える.このことから, TM-38 W と TM-140の性能は 良好であるが, TM-60 は同様に $65 \%$ となり，改良の 余地があると言える。

\section{結語}

市販の紫外線オゾン化装置について，閉鎖系室内 における性能を測定・評価した。

室容積を $4.5 \mathrm{~m}^{3}$ 及び $54 \mathrm{~m}^{3}$ の 2 室に拡大し, 3 機 種のオゾン化装置のテストを行い，各機種の室容積 と定常状態のオゾン濃度との関係やランプ入力と定 常状態のオゾン濃度との関係などを把握した。

また，実験を通して，一定入力の UV ランプによ るオゾンの光分解の見かけの速さがある室容積以上 では自然分解より遅くなる現象，寸なわち見かけの 「逆転容積」と, 一定容積の室内で UV ランプの入力 を減少させていくと, 光分解速度が自然分解速度よ り遅くなる現象，すなわち見かけの「逆転入力」を 新たに見い出した。

これらの結果から, 本装置 3 機種について次に示 すような全体的な評価を得た。

1）オゾン生成については室の大小に応じて若干 の変動はあるものの，1 時間以内に定常状態のオゾ ン濃度に達し，十分に用途に対応できるものである.

2）オゾンの分解においては，一般の実験室など ではオゾンランプ1灯に対してUVランプ1灯で は顕著な効果が少ない場合や，より速く必要なオゾ ン濃度の室内環境を提供するためには，ランプ 1 灯 の入力を增すか, 数灯の並列使用を行う必要がある.

3）極めて清浄な室内では，UVによるオゾンの 分解（スペースくりんなどの市販装置の使用）は大 変有効と考之られる.

以上の結果を利用すれば，本報で用いた 3 機種に ついて, 容積 $54 \mathrm{~m}^{3}$ 前後までの部屋におけるオゾン の生成・分解についての各種数值の予測が可能とな る.

また，スペースくりんと流動通過系の測定で扱っ たガラス製二重管装置とのオゾン生成能力を比較 し，TM-38 W と TM-140 はガラス製二重管装置の $90 \%$ の能力と評価した．また，TM-60は $65 \%$ であ り，改良の余地があることを指摘した。

このように，現状のオゾン化装置の性能を十分に 測定・評価することにより，必要なオゾン濃度の環 境をつくり出すことを一層容易にし, 装置設計者に 極めて有効な手掛りとなる数値を求めた。 


\section{引用 文 献}

1）村井忠道, 渡辺文夫, 医用衛生紫外線研究会誌, 1(2), 50 (1982).

2）渡辺文夫，照学誌，72，591（1988）。

3）渡辺文夫，照学誌， 73，57 (1989).

4）渡辺文夫, 霜村 修, 衛生化学, 35，426（1989）。

5）渡辺文夫，日化誌，7，732（1990）。

6）渡辺文夫，照学誌，75，288（1991）。

7）渡辺文夫，照学誌，75，307 (1991).

8) F. Watanabe, O. Shimomura, Jpn. J. Toxicol. Environ. Health, 37, 323 (1991).

9) F. Watanabe, O. Shimomura, Jpn. J. Toxicol. Environ. Health, 37, 337 (1991).

10）渡辺文夫, 福岡勝義, 大谷敏之, 衛生化学, 42, 142 (1996).

11) A.W. Ewell, Refrigerating Engineering, 26, 68 (1933).

12) A.W. Ewell, J. Appl. Phys., 13, 759 (1942).

13) L.R. Koller, J. Appl. Phys., 16, 816 (1945).

14）藤田重文, “化学工学 I, ”岩波全書, 東京, 1967, p.27. 